NBER WORKING PAPER SERIES

WAGE GROWTH AND JOB TURNOVER:

AN EMPIRICAL ANALYSIS

\author{
Ann P. Bartel \\ George J. Bor Jas
}

Working Paper No. 285

\author{
NATTONAL BUREAU OF ECONOMIC RESEARCH \\ 1050 Massachusetts Avenue \\ Cambridge MA 02138 \\ October 1978
}

This paper was presented at a conference on Low Income Labor Markets sponsored by the Universities - NBER Cormittee and funded by the National Science Foundation (Chicago, June 9-10, 1978). The research reported here is part of the NBER's research program in labor studies. Any opinions expressed are those of the authors and not those of the National Bureau of Economic Research. 
MAGE GRONTH AND JOB TURNOVER: AN EMPIRICAL ANALYSIS Ann P. Bartel and George J. Borfas

This paper dewonstrates that labor turnover is a eignificant factor in underetanding wage growth since it affects both wage growth across jobs and wage growth within the fob. our analysis shows that young wen who quit experience significant wage gains compared to stayers and compared to their own wage growth prior to the fob change. Among older mon, a quit increases wage growth only if the individual said he changed jobs because he found a better fob. Yet in both age groupa, Individual, who expect to remain on the current fob experience steeper wage growth per time period on that job. Thus labor turnover has offsetting effects on wage growth, leading to wage gains across fobs but flatter growth In shorter fobs. Our empirical analysis shows however that total iffe-cycle wage growth is positively related to current tenure. While early mobility may pay, Individuals who are etill changing jobs later in 11 fe experience lower overall wage growth.

Ann P. Bartel Columbla University Graduate School of Business 710 Or1s Hall New York, New York 10027 (212) 280-4419 
KAGE GROWTH AND JOB TURNOVER: AY EMPIRICAL ANALYSIS

Ann P. Bartel* and George J. Borfan*

The question of why an Individual's wages grow over and above economy-nide productivity growth is fundamental to the analyeis of the earninge diatribution. In fact, explanation of the earnings dietribution such as human capltal investments or random shock models are basically descriptions of the wage grouth process for an individual. 1 Daplte this Importance, and mainly due to the lack of longltudinal data for a given Individual, the cuplrical analysis of wage growth has lagged behind the capletcal analysie of wage levele. 2 This paper 1 a partial attempt to reandy this axyunetry. We focu on documenting how the exdstence of labor turnover syetematically affecte the rate of growth in wages both acrose jobs and within the job. It w111 be our working hypotheris to Interpret wage growth on the fob to be the result of human capital inveatmente, both general and specifle to the fob. We w111 also Interpret wage growth acrose jobs as balng due to changes in the Individual' human capital stock du to mobility" Investuante (e.g.. Bearch) and losses of apeciflc tralning Incurred when fob separation takes plece.

Given this framenork wo teckle two inportant question in labor economics. 3 The flrst is a variation of the old question of whether moblilty "pays." Note that the croes-section comparison of movers to stayers (or in the nigration literature, algrante to non-migranta) does not necessarily provide an anwer to the relevant questont does a person who noved during the time perlod under Inventigation do better 
than he would have done had he stayed? of course, the fact that the alternative wage is not observed once the individual's decision has been made has prevented researchers from answering this question. Recent econometric techniques dealing with selection bias in censored samples [Heckman (1978)] provide one method of approaching this problem. In this paper, however, we pursue a somewhat simpler approach that utilizes the longitudinal nature of our data. In particular, we will analyze the on-the-job progress of a given individual before and after the wove.

A second related question we will analyze is the effect of labor turnover on wage growth within the job. It is quite obvious that mobility shifts the earnings profile after each separation occurs. It is less obvious, but equally important, that an individual's intentions to separate from a firm will affect the rate of growth of his earnings in the current job. In particular, we hope to establish that job immobility (i.e., longer tenure) is associated with steeper wage growth than would occur otherwise for a given individual. 4 This finding should prove useful on several grounds. First of all, it establishes that Indeed wages grow with tenure for a given individual. Although this may seem like a somewhat trivial empirical result it should put to rest doubts about the interpretation of the observed positive relationship between wage levels and tenure. In particular, there exists the possibility that this positive correlation is entirely due to population heterogeneity. That is, there exists some unobserved individual characteristics which lead to low wages and high turnover rates for some persons, and to high wages and low turnover rates for other 
Individuals. Then a cross-section correlation of wages and tenure would be positive even if wagea did not grow at all in the job. 5 Nore Importantly, by establishing that wage growth on the fob 1s related to the separation probability, wo can obtain some estimates of the importance of specific training in the labor market. In partfcular, as long as specificity is an important component of human capital investmente, the human capital hypotheals predicts a positive correlation between investment costs per year and completed job tenure. Since lower probabilities of separation are associated with larger incentives to invest, we should observe steeper earnings profiles in longer fobs. Note that the prediction impiles not only that wages grow on the fob for a given individual, but that they grow faster the better the match (1.e., the longer tenure). Therefore, In a sense, the "gains to Imobolitty" are due to the fact that job tenure "matters" over and above the accunulation of labor market exposure.

The purpose of this paper, therefore, is to provide a systematic empirical analysis of the relationship between wage growth and fob turnover. We will use two data sete in the studys the National Longitudinal Surveys of Young and Mature Men. Section I provides a systematic examination of the relationship batween labor turnover and wage growth acrose fobs. Section II analyzes the effecte of job 1rmobility on wage growth. In section III we consider the implicatione of labor turnover for lifetime wage growth. Section IV briefly describes the effects of personal and labor market characteristics on individual wage growth. Finally, Section $V$ summarizes the results of the study. 
I. Labor Turnover and the Wage Proflle Across Jobs

In this section we use the NLS Young and Mature Men samples to analyze the effects of labor turnover on wage growth across jobs. There are several important restrictions in our use of the data. First of all we define labor mobility to occur when an individual changes employers. Thus transfers within the same firm are viewed as part of the returns to staying in the job. Secondly, to simplify the empirical analysis we do not attempt to distinguish between local movers and individuals who changed Jobs and migrated simultaneously. In other words, we Ignore the role of geographic mobility and its interaction effects with job turnover on wage growth. ${ }^{6}$ Third, our sample is composed of individuals who either did not change jobs at all in the perlod under investigation or who did not leave the labor force after the separation took place. Thus individuals who were either retired or in school at the beginning of the period or whose job separation was followed by either retirement or by a return to school are deleted from our sample. 7 For both data sets we concentrate on the interval between 1967 and 1973. and partition this long perlod into three two-year intervals, 1967-69, 1969-71, and 1971-73. We then pool the information in each of these Intervals across the individuals in our sample, in effect tripling the number of observations. 8 The labor turnover variable is defined to equal unity if the employer at the end of the two-year period is not the same as the employer at the beginning of the two-year interval. Part $A$ of this section reports the results of comparing the two-year price deflated wage growth of individuals who separated from their fobs during the perlod with the relevant wage increases reported by stayers. In 
Part $B$ we return to the question addressed earlier of whether mobility "pays" for a given individual.

\section{A. Comparing Movers to Stayers}

Table 1 contains coefficients on dummy variables that indicate the individual's mobility status over a two-year interval. These coefficients are taken from regressions using absolute or percentage wage growth over the two-year period as the dependent variable and holding constant a set of standardizing variables listed in the note to the table. 9 It is important to note that these standardizing variables are measured as of the beginning of the two-year period.

The coeficients of the separation dumies may be broadly interpreted as estimates of the "gains" to mobility. Table 1 shows that among the young men a quit is associated with an increase in earnings but for the older men a quit has either a negative or zero effect on wage growth. Thus, for example, young men who quit receive a wage increase of 11 cents an hour more than those who stayed, while for older men the wage increase is approximately minus 3 cents an hour. ${ }^{10}$ on the other hand, in both samples being laid off from a job leads to lower wage growth than for stayers, although in the young men's sample the difference is not very significant. For the older men, however, layoffs reduce wage growth over the two-year period by about 19 cents per hour. An interesting result is obtained by making a direct comparison of quits versus layoffs. In the case of young men, a quit is worth about 14 cents more than a layoff; while for the older men, a quit is worth 16.3 cents more than a layoff. Thus although who gains and loses relative to stayers varies over the life cycle, the gains to 
TABLE 1

The Effects of Turnover on Wage Growth Across Jobs Comparing Movers and Stayers Dependent Variable is $\Delta w$ or $\Delta I n W$ ( $t$-values are given in parentheses)

\begin{tabular}{|c|c|c|c|c|c|c|}
\hline & \multicolumn{3}{|c|}{ Absolute Growth } & \multicolumn{3}{|c|}{ Percentage Growth } \\
\hline & 1.1 & 1.2 & 1.3 & 1.4 & 1.5 & 1.6 \\
\hline & & A. & NLS Young Men & $(\mathrm{N}-3665)$ & & \\
\hline QUIT & $\begin{array}{r}.1139 \\
(2.02)\end{array}$ & & & $\begin{array}{r}.0184 \\
(1.31)\end{array}$ & & \\
\hline LNYOFF & $\begin{array}{l}-.0264 \\
(-.35)\end{array}$ & $\begin{array}{l}-.0397 \\
(-.53)\end{array}$ & $\begin{array}{l}-.0485 \\
(-.64)\end{array}$ & $\begin{array}{l}-.0253 \\
(-1.35)\end{array}$ & $\begin{array}{l}-.0299 \\
(-1.60)\end{array}$ & $\begin{array}{l}-.0322 \\
(-1.72)\end{array}$ \\
\hline JOBREL & & $\begin{array}{r}.1800 \\
(3.07)\end{array}$ & & & $\begin{array}{r}.0382 \\
(2.62)\end{array}$ & \\
\hline PERS & & $\frac{-.3545}{(-3.14)}$ & $\begin{array}{r}-.3605 \\
(-3.19)\end{array}$ & & $\begin{array}{r}-.1269 \\
(-4.53)\end{array}$ & $\begin{array}{r}-.1284 \\
(-4.59)\end{array}$ \\
\hline PUSH & & & $\begin{array}{l}.0540 \\
(.72)\end{array}$ & & & $\begin{array}{l}.0055 \\
(.30)\end{array}$ \\
\hline PULL & & & $\begin{array}{r}.2984 \\
(4.09)\end{array}$ & & & $\begin{array}{r}.0688 \\
(3.81)\end{array}$ \\
\hline & & B. & NLS Mature Mon & $(N=4745)$ & & \\
\hline QUIT & $\begin{array}{r}-.0259 \\
(-.29)\end{array}$ & & & $\begin{array}{l}-.0488 \\
(-2.05)\end{array}$ & & \\
\hline LAYOFF & $\begin{array}{c}-.1888 \\
(-2.08)\end{array}$ & $\begin{array}{r}-.1907 \\
(-2.10)\end{array}$ & $\begin{array}{r}-.1927 \\
(-2.13)\end{array}$ & $\begin{array}{r}-.0972 \\
(-4.00)\end{array}$ & $\begin{array}{r}-.0979 \\
(-4.03)\end{array}$ & $\begin{array}{r}-.0982 \\
(-4.04)\end{array}$ \\
\hline JOBREL & & $\begin{array}{c}.1342 \\
(1.31)\end{array}$ & & & .0047 & \\
\hline PERS & & $\begin{array}{c}-.4641 \\
(-2.81)\end{array}$ & $\begin{array}{l}-.4651 \\
(-2.82)\end{array}$ & & $\begin{array}{l}-.1951 \\
(-4.42)\end{array}$ & $\begin{array}{r}-.1953 \\
(-4.43)\end{array}$ \\
\hline PUSH & & & $\begin{array}{c}-.0973 \\
(-.79)\end{array}$ & & & $\begin{array}{r}-.0283 \\
(-.85)\end{array}$ \\
\hline PULL & & & $\begin{array}{r}.5999 \\
(3.46)\end{array}$ & & & $\begin{array}{l}.0711 \\
(1.53)\end{array}$ \\
\hline
\end{tabular}

ather variables held constant are EDUC, EXPER, JOB, ARUY, UNION, HLTH, MAR, WLPP, WN, WKSUN, SIZE, UN, D67, D69. 
quitting as opposed to being laid off remain relatively constant with age.

of course, it is not surprising that quitters do better than individuals who were laid off at all ages. What is purzling is that quitters do not do better than stayers systematically over the life cycle. Further analysis of this result can be conducted with the information provided in the NLS on the reasons for the quit. Thus we decompose the variable QUIT (= 1 if change was voluntary, 0 otherwise) Into two kinds of voluntary changess a quit that is due to job-related reasons and a quit that 18 due to personal reasons. 11 The reader should, of course, note that these reasons are reported after the separation took place and hence there may be some element of rationalization on the worker's part which may contaminate the results we report. The coefficients of JOBREL (job-related quite) and PERS (personal quits) are shown in columens 1.2 and 1.5 of Table 1 . The results are quite striking. In both samples we now find that individuals who quit for personal reasons had significantly smaller wage growth than stayers, while men who had a job-related quit experienced higher wage growth than stayers. This latter effect is quite significant for the young men's sample, but less significant in the older men NLS. The results, therefore, imply a very significant differential in the gains from quitting by reason of quitting. Moreover, it is also of interest to note that layoffs and quits for personal reasons have similar qualitative effects on wage growth. This might be due to the fact that both these types of separations have a large exogenous and unexpected component, so that these individuals would have had less search while on the fob than individuals whose quit was premeditated. 
A further decomposition of the variable QUIT is examined in colunns 1.3 and 1.6 by segmenting fob-related quits into quits due to dissatisfaction with the current fob (PUSH) and quits occurring because the individual found a better fob (PULL). ${ }^{12}$ One may argue that it is irrelevant whether the change was due to a pull or a push since basically the voluntary separation occurred because the individual's opportunities were better in the new job. That 1s, it is irrelevant whether the quit was due to the fact that the present fob was bad or to the fact that the new job was better. Elther way, the new fob improved the Individual's situation relative to the old job. Although essentially correct, this line of argument ignores an empirical peculiarity of the data: most of the individuals who sald they were pushed from the current job gave reasons relating to the non-wage aspects of the job. Thus there is no obvious reason to expect any kind of wage increase for this group. Indeed, Table 1 shows that the effect of quits on wage growth differs significantly depending on whether the quit was a pull or a push. Thus a pull always leads to elgnificantly higher wage growth than that experienced by stayers while a push does not seem to affect wage growth at all. In general, the results in Table 1 suggest that the nature of a quit is a very important determinant of the gains to mablifty. Moreover, the results obtained with the detalled decomposition of QUIT provide one explanation, though not a very convincing one, of the fact that the QUIT coefficient varies over the life cycle. In particular, a quit is more likely to be due to finding a better job at younger ages, while at older ages the quit is mainly due to dissatisfaction with the current job. These results, however, are not 
entirely consistent with the matching view of labor turnover since the matching process--and therefore quits due to dissatisfaction with the present employer--1s more likely to take place early in the life cycle. The fact that our data show the opposite is somewhat puzzling.

Finally, one way of measuring the magnitude of the wage increase due to PULC is to calculate the present value of this increase assuming both that the individual works full-time untll his retirement and that the wage increase due to the quit is goneral in the sense that it remains with him throughout his working $11 f e .^{13}$ from colum 1.3 the observed wage increase is worth $\$ 2,940$ for the young men and $\$ 570$ for the older wen. Obplously the longer payoff pertod for young men clearly increases the return on mobility investment.

\section{B. Wage Growth Prior to, During, and After the Move}

In the previous section we conducted an analysis calculating the "gains" to mobility by comparing movers to stayers. As was pointad out earlier, this procedure could create problems if population heterogeneity is an important phenomenon in the labor market. The existence of heterogeneity raises two distinct types of problems. First, the separation dumbies that compare movers to stayere can be proxying unobserved Individual characteristics indicating both the propensity for turnover and the Individual's ablilty to "grow" on the job. Since individuals with high propensities for turnover find it harder to "hold onto a job," population heterogenelty would create a negative correlation between wage growth and the separation probabilities. Moreover, if one reason stayers stay in the job is their better progress (or prospects for progress), clearly this would further bias downards the "gaine" to mobility. 
Thus unless we resort to somewhat more complicated statistical procedures, ordinary least squares comparisons of movers to stayers will yield hopelessly biased estimates of the returns to moving. A correct answer to the question of whether the individual gained by moving can be obtained only by a comparison of the individual's new wage progress to that which he would have obtained had he stayed at the previous Job. Clearly the relevant alternative wage is unavallable once the individual's separation decision is taken. A simple approximation, however, exists if we utilize fully the longitudinal nature of our data. For example, suppose we have a sample of individuals who either did not change fobs between 1967 and 1973 or who changed only during 1969 and 1971. Thus the basic difference between the two groups of men lies in their 1969-71 separation propensities. Suppose that we estimate wage growth equations similar to those given in columns 3 and 6 of Table 1 for each of the subperiods: 1967-69, 1969-71, and 1971-73 as a function of the 1969-71 separation probabilities. The coefficients on these dummies can then be studled to show how the mover's wages were growing before he changed fobs, during the period in which he changed fobs, and after the Job change took place. If we are willing to assume that the offect of the 1969-71 mobility dummy on 1967-69 wage growth 18 indicative of how movers were doling in the fob prior to separation, we can then determine conclusively whether a mover gained from moving by analyzing the behavior of the separation dumiles over the six-year period. In particular, the individual improved his situation by moving if the mobility coefficient is more positive after the move 
than before the move. Thus by looking at changes in the mobility coefficient we are, in effect, controlling for population heterogeneity since these unobserved individual characteristica are assumed to be constant over time.

The results of estimating these equations are presented in Table 2. Panels $A$ and $B$ give the results for young and older men using the sample of men who elther moved during 1969-71 only or who did not move at all during the six-year period. To show how these resulte should be interpreted, consider In detall the effect of being "pushed" from the 1969 job on the wage profile of young men. We find that prior to the meparation, Individuals who were "pushed" from the fob had eignificantly lower wage growth than individuals who stayed in that job subsequently. Two factors explain this result. Clearly, the movers were not progressing well on the job and eventually quit because of this. Secondly, if the fob was a mismatch, as it eventually turned out to be, and if this information was known to both firm and worker, the incentives for investment in the job were weak, leading to smaller wage growth. 14 During the 1969-71 period, when the move actually occurred, we find that these same Individuals had larger wage growth than sayers. Again, assuming that the difference between movers and stayers in the 1967-69 period was the correct comparison between the mover's old job and the stayers' Job, clearly the positive coefficlent of PUSH on 1969-71 wage growth provides very strong evidence that the movers improved their situation significantly through job moblilty. Moreover, we find that these gains were not temporary since the comparison of movers to stayers in the 1971-73 period (after the move took place) yields the finding that 
TABLE 2

The Effects of Turnover on Wage Growth Across Jobs Comparing Individuals to Themselves

Dependent Variable is $\Delta w$ or $\Delta \mathrm{ln} w$ ( $t$-values are given in parentheses)

\begin{tabular}{|c|c|c|c|c|c|c|}
\hline & \multicolumn{3}{|c|}{ Absolute Growth } & \multicolumn{3}{|c|}{ Percentage Growth } \\
\hline & $67-69$ & $69-71$ & $71-73$ & $67-69$ & $69-71$ & $71-73$ \\
\hline & & A. & NLs Young & $\operatorname{Men}(N=392)$ & & \\
\hline LAYOPF & $\begin{array}{l}.0885 \\
(.57)\end{array}$ & $\begin{array}{l}-.0391 \\
(-.23)\end{array}$ & $\begin{array}{l}.0579 \\
(.47)\end{array}$ & $\begin{array}{r}.0785 \\
(1.24)\end{array}$ & $\begin{array}{l}.0201 \\
(.39)\end{array}$ & $\begin{array}{r}.0575 \\
(1.14)\end{array}$ \\
\hline PERS & $\begin{array}{l}-.1250 \\
(-.59)\end{array}$ & $\begin{array}{r}-.3029 \\
(-1.34)\end{array}$ & $\begin{array}{l}2169 \\
(.80)\end{array}$ & $\begin{array}{r}-.0320 \\
(-.37)\end{array}$ & $\begin{array}{l}-.1223 \\
(-1.75)\end{array}$ & $\begin{array}{r}.1347 \\
(1.95)\end{array}$ \\
\hline PUSH & $\begin{array}{l}-.2455 \\
(-1.66)\end{array}$ & $\begin{array}{r}.3083 \\
(1.94)\end{array}$ & $\begin{array}{l}-.0440 \\
(-.23)\end{array}$ & $\begin{array}{l}-.0693 \\
(-1.15)\end{array}$ & $\begin{array}{r}.1105 \\
(2.26)\end{array}$ & $\begin{array}{l}.0153 \\
(.32)\end{array}$ \\
\hline PULL & $\begin{array}{r}-.1027 \\
(-.57)\end{array}$ & $\begin{array}{r}.6174 \\
(3.23)\end{array}$ & $\begin{array}{r}.3287 \\
(1.44)\end{array}$ & $\begin{array}{l}.0384 \\
(.53)\end{array}$ & $\begin{array}{r}.1784 \\
(3.02)\end{array}$ & $\begin{array}{r}.0599 \\
(1.03)\end{array}$ \\
\hline & & B. & NLs Mature & $\operatorname{Men}(N=1016$ & & \\
\hline LAYOFP & i.2111 & $\begin{array}{l}-.5501 \\
(-2.80)\end{array}$ & $\begin{array}{l}1534 \\
(.69)\end{array}$ & $\begin{array}{r}.0802 \\
(1.75)\end{array}$ & $\begin{array}{l}-.1818 \\
(-3.45)\end{array}$ & $\begin{array}{l}.0579 \\
(.95)\end{array}$ \\
\hline PERS & $\begin{array}{l}-.2156 \\
(-.44)\end{array}$ & $\begin{array}{l}-1.1024 \\
(-2.46)\end{array}$ & $\begin{array}{l}-.1143 \\
(-.23)\end{array}$ & $\begin{array}{r}-.0301 \\
(-.29)\end{array}$ & $\begin{array}{l}-.3780 \\
(-3.13)\end{array}$ & $\begin{array}{l}.0062 \\
(.04)\end{array}$ \\
\hline PUSH & $\begin{array}{l}.1202 \\
(.32)\end{array}$ & $\begin{array}{l}-.0932 \\
(-.27)\end{array}$ & $\begin{array}{r}-.2345 \\
(-.59)\end{array}$ & $\begin{array}{r}.0129 \\
(.16)\end{array}$ & $\begin{array}{l}-.0437 \\
(-.47)\end{array}$ & $\begin{array}{c}-.0098 \\
(-.09)\end{array}$ \\
\hline PULL & $i^{1083}$ & $\begin{array}{l}-.6126 \\
(-1.37)\end{array}$ & $\begin{array}{r}-.7372 \\
(-1.45)\end{array}$ & $\begin{array}{l}.0407 \\
(.39)\end{array}$ & $\begin{array}{l}-.0656 \\
(-.54)\end{array}$ & $\begin{array}{r}-.1102 \\
(.79)\end{array}$ \\
\hline
\end{tabular}


TABLE 2 (concluded)

\begin{tabular}{|c|c|c|c|c|c|c|}
\hline & \multicolumn{3}{|c|}{ Absolute Growth } & \multicolumn{3}{|c|}{ Percentage Growth } \\
\hline & $67-69$ & $69-71$ & $71-73$ & $67-69$ & $69-71$ & $71-73$ \\
\hline & \multicolumn{3}{|c|}{ c. } & \multicolumn{2}{|c|}{ 1032) } & \\
\hline IAYOPP & $\stackrel{.0922}{(1.90)}$ & $(1.40)$ & $\begin{array}{l}-.5305 \\
(-.43)\end{array}$ & $(1.0515$ & $\begin{array}{l}.0163 \\
(.60)\end{array}$ & $\begin{array}{l}-.0069 \\
(-.22)\end{array}$ \\
\hline PERS & $\begin{array}{l}-.1040 \\
(-.80)\end{array}$ & $\begin{array}{r}-.1187 \\
(-.92)\end{array}$ & $\begin{array}{l}.0417 \\
(.22)\end{array}$ & $\begin{array}{l}-.0223 \\
(-.41)\end{array}$ & $\begin{array}{r}-.0465 \\
(-1.09)\end{array}$ & $\begin{array}{l}.0521 \\
(1.07)\end{array}$ \\
\hline PUSH & $\begin{array}{r}-.1801 \\
(-1.91)\end{array}$ & $\begin{array}{r}.1637 \\
(1.75)\end{array}$ & $\begin{array}{l}-.0467 \\
(-.34)\end{array}$ & $\begin{array}{l}-.0363 \\
(-.91)\end{array}$ & $\begin{array}{l}.0535 \\
(1.74)\end{array}$ & $\begin{array}{l}-.0028 \\
(-.08)\end{array}$ \\
\hline PUTL & $\begin{array}{c}-.0033 \\
(-.03)\end{array}$ & $\begin{array}{c}.2202 \\
(2.01)\end{array}$ & $\begin{array}{l}-.0197 \\
(-.12)\end{array}$ & $\begin{array}{r}.0477 \\
(1.02)\end{array}$ & $\begin{array}{c}.0587 \\
(1.62)\end{array}$ & $\begin{array}{l}-.0144 \\
(-.35)\end{array}$ \\
\hline & & D. & NLS Mature & $\operatorname{Men}(N=1$ & 79) & \\
\hline IAYOSF & $\begin{array}{l}1552 \\
(.89)\end{array}$ & $\begin{array}{r}-.1687 \\
(-1.00)\end{array}$ & $\begin{array}{r}-.1519 \\
(-.82)\end{array}$ & $\begin{array}{l}.0183 \\
(.47)\end{array}$ & $\begin{array}{r}-.0455 \\
(-1.03)\end{array}$ & $\begin{array}{l}-.0518 \\
(-1.08)\end{array}$ \\
\hline PERS & $\begin{array}{l}-.2006 \\
(-.55)\end{array}$ & $\begin{array}{l}-.3616 \\
(-1.03)\end{array}$ & $\begin{array}{r}.4840 \\
(1.24)\end{array}$ & $\begin{array}{l}-.0096 \\
(-.12)\end{array}$ & $\begin{array}{r}-.1559 \\
(-1.68)\end{array}$ & $\begin{array}{r}.1579 \\
(1.56)\end{array}$ \\
\hline POSH & $\begin{array}{r}.0220 \\
(.08)\end{array}$ & $\begin{array}{l}-.0223 \\
(-.08)\end{array}$ & $\begin{array}{r}-.1771 \\
(-.58)\end{array}$ & $\begin{array}{l}-.0340 \\
(-.53)\end{array}$ & $\begin{array}{l}.0327 \\
(.45)\end{array}$ & $\begin{array}{l}-.0248 \\
(-.31)\end{array}$ \\
\hline PULC & $\begin{array}{l}-.0096 \\
(-.03)\end{array}$ & $\begin{array}{l}-.1769 \\
(-.44)\end{array}$ & $\begin{array}{l}.1511 \\
(.34)\end{array}$ & $\begin{array}{l}.0294 \\
(.32)\end{array}$ & $\begin{array}{c}-.0016 \\
(.00)\end{array}$ & $\begin{array}{l}-.0453 \\
(-.39)\end{array}$ \\
\hline
\end{tabular}

The variables (excluding JOB) held constant in Table 1 are held constant here. 
there is no difference in the wage progress of the two groups. Therefore, we can safely conclude that individuals who moved used job mobilIty as a tool to achieve a better wage package.

The reader can easily verify that almost (qualitatively) identical results are obtained for the other types of voluntary separations in the NLS Young Men's sample. For the mature men, this exercise yields somewhat mixed results. The reason is probably due to the fact that the separation dumies have very low means. For example, the frequencles of PUSH, PULL and PERS are .0098, .0059, and .0059, respectively. It may be argued that these findings are seriously biased by the existence of a selectivity bias since our sample consists of individuals who either did not change jobs at all or who moved in only the 1969-71 period, so that the move was, in a sense, successful. In fact, the use of an unrestricted sample where we include all individuals and relate their wage growth in all three perlods to their 1969-71 separation behavior, barely affects our results as can be seen in Panels C and $D$ of Table 2. If anything, we obtain somewhat more reasonable results for the mature men.

II. Labor Turnover and Wage Growth Within the Job

In the previous section we have shown that labor turnover affects the wage profile across jobs. In this section we demonstrate how labor turnover also affects the earnings profile within the job. In Part A we present a simple framework for analyzing the relationship between labor turnover and on-the-job wage growth and in Part B we document empirically that labor turnover systematically affects the slope of the earnings profile within the job. 


\section{A. A Framework for Analyzing On-the-Job Wage Growth}

One way in which on-the-fob wage growth can be studied is to interpret it as the result of human capital investment. If no mobility occurs during the period $t-1$ to $t$, then the absolute change in the individual's earnings capacity during that period can be written as:

$$
\Delta E_{t}=E_{t}-E_{t-1}-r_{n} C_{t-1}
$$

where $E_{t}$ is earnings capacity at experience year $t, C_{t}$ denotes dollar investment costs in $t_{;}$and $r_{n}$ is the rate of return to post-school investments on the current $\left(n^{\text {th }}\right.$ ) job. Note that $c_{t}$ is composed of all investment costs borne by the individual. That is, it is composed of general investments as well as the share of specific training costs paid by the individual.

The change in earnings capacity given by equation (1) is unobserved. However, if all investment costs are foregone earnings, observed earnings, $Y_{t}$, are defined by $Y_{t}=E_{t}-C_{t}$. Thus equation (1) can be rewritten as:

$$
\Delta Y_{t}=r_{n} C_{t-1}-\left(C_{t}-C_{t-1}\right)=r_{n} C_{t-1}+B_{n}
$$

where $\beta_{n}=-\left(c_{t}-C_{t-1}\right)$. Since, by assumption, no fob change has occurred, observed wage growth on the fob is composed of the returns to on-the-fob training plus the change in investment costs from period to period. If the investment profile is assumed to be continuous and 1 inearly declining (within the fob), the change in investment costs is given by the constant rate of decline in investment in the current fob, $\beta_{n}$. Thus observed wage growth incorporates the saving in investment costs as fob tenure increases. 
To convert equation (2) into observables, we hypothesize that investment costs are a negative function both of previous experience and of current job experience. ${ }^{15}$ That 1s, more investment is undertaken the younger the individual was when he started the job and the shorter the tenure on the job. Of course, both these implications must bo qualified by the fact that at low levels of tenure there is a considerable amount of learning taking place as both the individual and firm consider whether the job match is worthwhile. Moreover, at younger ages, as the individual learns about the labor maxket, "job shopping" might lead to an initial increase in investment. Thus it is possible that human capital investments may be zero or rise initially both with age and with job tenure. We assume that these matching periods are reasonably short so that our linear approximations do not greatly distort reality. In particular, if $\pi_{n}$ measures experience prior to the current job and $e_{n}$ measures current fob tenure, a simple relation determining investment costs would be 16

$$
c_{t}=c_{\text {on }}-\sigma_{n} \pi_{n}-B_{n} e_{n}
$$

Note that $C_{\text {on }}$ measures the level of investment that would take place initially if the current job were the first job in the life cycle. Substituting (3) into (2) yields:

$$
\Delta Y_{t}=\left(r_{n} C_{o n}+\beta_{n}+r_{n}^{\beta}\right)-r_{n} \sigma_{n} \pi_{n}-r_{n}^{\beta} e_{n}
$$

Thus a simple regression of wage growth on previous and current experience gives coefficients that are proportional to the effect of aging both prior to the job and within the job. 
We can introduce the relationship between labor turnover and onthe-fob wage growth by noting that $c_{\text {on }}$ will vary systematically with the probability of separation. That is, since a part of dollar investment coste 18 specific to the current fob, there will be a positive correlation between the level of the investment profile (measured by $C_{\text {on }}$ ' and expected completed job duration. In other words, the individual (and the firm) will invest more in longer fobs because they can both collect the returns to specific training over a longer period of time. Simultaneously, those individuals who have invested more on the fob will have an incentive to stay longer. 17 Denoting $t_{n}$ as expected completed tenure in the job as of the beginning of the job, this implies:

$$
c_{\text {on }}=\alpha_{n}+p_{n} t_{n}^{*}
$$

If longitudinal data are used, information on $t_{n}$ is generally avallable as long as actual events closely parallel expectations. If we make the simplifying assumption that actual completed tenure equals $t_{n}$ as a first-order approximation, and if we observe a sample of individuals changing fobs at some point during the survey, then it is possible to estimate the parameter $p_{n}$ (times a constant). In particular, rewrite $t_{n}^{\star} \mathbf{a s}$ :

$$
t_{n}^{*}=e_{n}+R_{n}
$$

where $e_{n}$ is current job tenure and $R_{n}$ is time remaining in the current job. Using equations $(4)-(6)$ we can derive: 


$$
\Delta Y_{t}=\left(r_{n} \alpha_{n}+\beta_{n}+r_{n} \beta_{n}\right)-r_{n} \sigma_{n} \pi_{n}+r_{n}\left(p_{n}-\beta_{n}\right) e_{n}+r_{n} p_{n} R_{n}
$$

The human capital hypothesis would predict that the coefficient on $R_{n}$ is positive, 1.e., wage growth is steeper in longer fobs. It is important to note that this relationship cannot be measured by observIng the coefficient on current tenure, ${ }_{n}$. As equation (7) shows, the coefficient on $e_{n} 18$ ambiguous because longer observed tenure las of the time of the survey) implies both that the individual is older (the aging effect $B_{n}$ ' and that more will be invested since for given $R_{n}$ the job will be longer (the investment effect $p_{n}$ ). The key to demonstrating that labor turnover and on-the-job wage growth are related is the avallability of longitudinal data which enable us to observe an individual's completed tenure. 18

It is important to note, however, that an alternative interpretation can be given to the observation of a positive coefficient on $R_{n}$. One could simply argue that in fobs where an individual is progressing, 1.e. where his wages are growing faster than they would elsewhere (perhaps because of better opportunities for investment), the Individual will have an incentive to stay. Again, we would observe a positive correlation between on-the-job wage growth and completed fob tenure. Actually, elther interpretation highlights the importance of human capital in explaining labor turnover. 
B. Epirical Results on Wage Growth Within the Job

Table 3 presents the results of estimating equation (7) on both NLS samples. In both cases, we selected a group of individuals who had stayed on the fob botween 1967 and 1969 but who had changed fobs at any time during 1969 and 1973. Thus we have a sample of individuals for whom time remaining on the job is observed. ${ }^{19}$ The equations In Table 3 relate wage growth in 1967-69 to previous experience (PREV), current fob tenure (JOB), time remining on the fob measured as of 1967 (REMTEN), and a set of standardizing variables listed in the footnote to Table 1. As before, the wage growth equations are estimated in two alternative ways: in column 3.1, the absolute change in wages over the 1967-69 period is the dependent variable, while in column 3.2, the percentage change in wages is analyzed.

Although the results are not statistically very strong, the coefficient of time ramaining on the Job, REMTEN, has the right aign and seems to be more significant for the older men sample. 20 For example, an extra year of fob tenure in the older men sample increases the hourly wage rate by about 2.5 cents more over the two-year time period under investigation. An interesting exercise that can be carried out is to ask how much does the positive correlation between completed tenure and wage growth contribute to total wage gains on the job? This calculation can be done roughly in the following way. First of all, in terms of yearly earnings (1.0., 2,000 hours supplied to the labor market), we obtain the increase in annual earnings of expecting to stay one additional year on the job by multiplying .0125 by $2,000,21$ 
TABIA 3

Effects of "Time Remaining on the Job" on 1967-69 Wage Grouth ${ }^{\mathrm{a}, \mathrm{b}}$

\begin{tabular}{|c|c|c|c|}
\hline & $\begin{array}{c}3.1 \\
\text { Absolute }\end{array}$ & & $\begin{array}{c}3.2 \\
\text { Percentage }\end{array}$ \\
\hline & $Y_{69}-Y_{67}$ & & $\ln Y_{69}-\ln Y_{67}$ \\
\hline & A. NLS & Young Men & $(\mathrm{N}=156)$ \\
\hline PREV & $\begin{array}{c}-.0120 \\
(-.56)\end{array}$ & & $\begin{array}{l}-.0109 \\
(-1.53)\end{array}$ \\
\hline JOB & $\begin{array}{l}-.0500 \\
(-1.47)\end{array}$ & & $\begin{array}{l}-.0225 \\
(-2.00)\end{array}$ \\
\hline \multirow[t]{2}{*}{ REATEN } & $\begin{array}{l}.0827 \\
(.87)\end{array}$ & & $\begin{array}{l}.0238 \\
(.76)\end{array}$ \\
\hline & B. NLS & Mature Men & $(N=747)$ \\
\hline PREV & $\begin{array}{l}-.0144 \\
(-2.13)\end{array}$ & & $\begin{array}{l}-.0045 \\
(-1.62)\end{array}$ \\
\hline JOB & $\begin{array}{l}-.0195 \\
(-2.90)\end{array}$ & & $\begin{array}{l}-.0062 \\
(-2.25)\end{array}$ \\
\hline REATTESN & $\begin{array}{l}.0241 \\
(1.26)\end{array}$ & & .0013 \\
\hline
\end{tabular}

The variables held conatant in Table 1 (except D67 and D69) are also held constant here.

The sample is restricted to individuals who stayed on the job between 1967 and 1969 but left that job between 1969 and 1973. 
this amount is $\$ 25.70$. The individuals in our sample, in fact, stayed 20 years on the fob (15 years prior to the survey and 5 after the survey). Therefore, from an ex ante polnt of view, staying an additional 20 years on the job is equivalent to an increase in annual earnings of \$514. The present value of this increase in annual earnings over the completed fob span (20 years of tenure) 1s $\$ 4,446$. Thus there is substantial wage growth on the fob over and above that obtained if there were no positive correlation between wage growth and completed fob tenure. In the case of young men, even though the coefficient of REMTEN 1s 8.4 cents, the completed tenure is significantly smaller, only 6.6 years (2.9 years before the survey, 3.7 years after the survey). Thus the present value of the wage gains due to the correlation between completed fob tenure and wage growth is $\$ 2,700 .^{22}$ of course, we recognize that the insignificance of REMTEN in our equations indicates the need for further research on this question.

\section{Labor Turnover and Lifetime Wage Growth}

Parts I and II of our paper have shown the role that labor turnover plays in determining wage growth both across jobs and within the fob. We have observed that individuals who change fobs voluntarlly experience wage gains while individuals who stay on the fob appear to experience steeper wage growth within the fob. Thus one can not predict a priori whether turnover leads to smaller or larger lifetime wage growth. In this section we suggest how this question can be answered.

It might seem appropriate to estimate an earnings function of the form:

$$
y_{t}=a_{0}+a_{1} t+a_{2} t^{2}+a_{3} e+a_{4} e^{2}
$$

where $t$ is total labor force experience and denotes current job tenure. 
This type of earnings function 18 essentially based on the argument that on-the-job training is composed both of general and specific training. The coefficients of $t$ capture the growth of the individual over the life cycle, while the coefficients of e measure any growth which is specific to the current job over and above the growth which would have occurred due to general labor force experience. Thus, in principle, the estimation of (8) would provide some insight into the importance of Job specific skills in determining the abserved wage structure. Unfortunately, a problem with this interpretation arises when (8) is applied to a cross-section of individuals. In particular, consider an extreme case in which there is no specific training and thus $\alpha_{3}$ and $\alpha_{4}$ are truly zero. If individuals self-select themselves into different types of fobs because they differ in their propensities to separate--in other words, there is population heterogeneity--1t may be that individuals who match into a "good" job recelve high wages and therefore show low propensities to separate and individuals with "bad" matches receive low wages and are therefore observed to have high propensities to separate. 23 In this case, in the cross-section $\alpha_{3}$ may turn out to be positive artificially: Thus the cross-section estimates of (8) may not be very meaningful in analyzing the relationship between turnover and iffetime wage growth. Using longitudinal data, however, we can provide a solution to this problem. In particular, consider the equation:

$$
Y_{t}-Y_{0}=\gamma_{1} t+Y_{2} t^{2}+Y_{3} e+Y_{4} e^{2}
$$

where $Y_{0}$ gives earnings in the first year of the life cycle. Thus by 
looking at wage growth we net out any individual differences that are unobserved but affect the individual's earnings throughout the life cycle. The coefficients $\gamma_{1}(1=1, \ldots$ 4) can be interpreted as the effecte of experience and job tenure on total life cycle wage progress. In particular, consider the extreme case in which there is no specific training. clearly the coefficients $\gamma_{1}$ and $\gamma_{2}$ simply capture sane offects and are expected to be positive and nogative respectively. If there is only general tralning, there is no obviou reason as to why length of current job tenure provides any additional information on total life cycle wage growth. In fact, if mobility "pays" (that is, thare are non-negative gains associated with changing fobs), longer tenure inplies a emaller propensity for eeparation. If there is serial correlation in this propensity over the individual's life cycle, this inplies less turnover in the individual's previou experience $t-a$. But under the aseunption that wobllity paya, the net effect of current tenure should then be negative: On the other hand, if wage progress over the life cycle is a function not only of total experience but of current job tenure, we would expect $r_{3}$ and $r_{4}$ to be positive and negative respectively in equation (9). If this is the case, however, the resulte can be interpreted an an indication of the fact that specific training is an important component of wage detornination. ${ }^{24}$ In other words, job tenure matters over and above the passage of labor market exposure.

Unfortunately, the two data sets we use in this paper do not contain any information on Initlal earnings in the life cycle. Moreover, In the Young Men NLS the individuals are much too young and both labor 
market experience and job tenure too short to get any robust estimates of the parameters. However, in the older men NLS we do have a measure of labor market progress made by the individual over the ilfe cycle since we are given the Duncan scale for the inftlal and current occupations. One distinct advantage of using the Duncan scale is the fact that the measure of "earnings" is of a more permanent nature. 25 Table 4 presents the lifetime earnings growth regression estimated for the older Men NLS. In each case the linear fob tenure coefficient is positive and significant indicating that holding total labor force experience constant, longer fob tenure is associated with higher levels of total iffe cycle wage growth. Therefore, the results unambiguously show that while mobility that takes place early in the life cycle may pay, individuals who have finally settled in a firm experience larger lifetime wage growth than individuals who are still changing fobs.

\section{Effects of Other Variables}

In the previous sections we have documented that turnover is an important determinant of wage growth. In this section we explore in more detall the other determinants of wage growth for both the Young and Mature NLS samples. The basic results are presented in Table 5 where wage growth regressions are estimated separately for stayers, quitters and layoffs in both age samples. In order to conserve space we present only the results using arithmetic wage growth.

The effects of the other variables are interesting. For example, education has a strong positive effect on the wage growth of young men. Moreover, within the young men's sample, education 
TABLE 4

Effects of Job Tenure on Iffetime Wage Growth

\begin{tabular}{|c|c|c|}
\hline & \multicolumn{2}{|c|}{$\begin{array}{l}\text { NLs Mature Men } \\
\text { DEP }=Y_{t}-Y_{0}\end{array}$} \\
\hline & Coefficient & $t$ \\
\hline Constant & -24.1973 & \\
\hline EDUC & .4470 & $(2.13)$ \\
\hline EXPER & 1.8399 & $(2.04)$ \\
\hline $\operatorname{EXPER}^{2}$ & -.0284 & $(-2.23)$ \\
\hline JOB & .4860 & (3.29) \\
\hline $\mathrm{JOB}^{2}$ & -.0077 & $(-1.78)$ \\
\hline $\mathrm{R}^{2}$ & & \\
\hline
\end{tabular}


TABIE 5

Effects of Other Variables on Vage Growth

Dependent Variable is $\Delta Y_{t}$

\begin{tabular}{|c|c|c|c|c|c|c|}
\hline & \multicolumn{6}{|c|}{ Young Men } \\
\hline & \multicolumn{2}{|c|}{ Stayers } & \multicolumn{2}{|c|}{ Quitters } & \multicolumn{2}{|c|}{ Layoffs } \\
\hline & Coeff. & $t$ & Coeff. & $t$ & Coeff. & $t$ \\
\hline D67 & .0020 & $(.03)$ & .0927 & $(.54)$ & .2099 & $(1.12)$ \\
\hline D69 & -.0467 & $(-.40)$ & -.0331 & $(-.08)$ & -.0806 & $(-.23)$ \\
\hline EDOC & .0250 & $(2.69)$ & .0710 & $(2.35)$ & .0796 & $(2.71)$ \\
\hline EXPER & -.0094 & $(-1.40)$ & .0123 & $(.53)$ & .0103 & $(.49)$ \\
\hline JOB & -.0068 & $(-.94)$ & -.0488 & $(-1.40)$ & .0209 & $(.59)$ \\
\hline ARYY & -.0018 & $(-1.27)$ & -.0028 & $(-.57)$ & -.0005 & $(-.11)$ \\
\hline UNION & -.0713 & $(-1.80)$ & -.1051 & $(-.66)$ & -.0766 & $(-.55)$ \\
\hline HLTH & -.0684 & $(-1.02)$ & -.2184 & $(-1.08)$ & -.0959 & $(-.53)$ \\
\hline MaR & .0934 & $(1.90)$ & -.0883 & $(-.53)$ & -.2598 & $(-1.61)$ \\
\hline WRP & -.1032 & $(-1.83)$ & .0855 & $(.44)$ & .5517 & $(2.51)$ \\
\hline WINC & .0014 & $(1.06)$ & .0033 & $(.75)$ & -.0057 & $(-.98)$ \\
\hline WRSUN & -.0023 & $(-.51)$ & -.0027 & $(-.26)$ & .0054 & $(.96)$ \\
\hline SIZE & .0057 & $(3.09)$ & .0140 & $(2.12)$ & .0020 & $(.31)$ \\
\hline UN & -.0086 & $(-.75)$ & .0010 & $(.03)$ & .0381 & $(1.01)$ \\
\hline$R^{2}$ & .029 & & .021 & & .049 & \\
\hline $\mathbf{N}$ & 2145 & & 1046 & & 474 & \\
\hline
\end{tabular}


TABLE 5 (concluded)

\begin{tabular}{|c|c|c|c|c|c|c|}
\hline & \multicolumn{6}{|c|}{ Mature Man } \\
\hline & \multicolumn{2}{|c|}{ stayers } & \multicolumn{2}{|c|}{ Quitters } & \multicolumn{2}{|c|}{ Layof Is } \\
\hline & Coefe. & $t$ & Coeff. & $t$ & Coete. & $t$ \\
\hline $\mathrm{D} 67$ & .0531 & $(.97)$ & 1.124 & $(2.24)$ & .7686 & $(3.68)$ \\
\hline D69 & -.0078 & $(-.14)$ & .6508 & $(1.28)$ & .5883 & $(2.86)$ \\
\hline EDOC & .0033 & $(.41)$ & .1082 & $(1.71)$ & -.0061 & $(-.19)$ \\
\hline EXPER & -.0081 & $(-1.68)$ & .0731 & $(1.83)$ & .0105 & $(.54)$ \\
\hline JOB & .0011 & $(.60)$ & -.0266 & $(-1.36)$ & -.0019 & $(-.25)$ \\
\hline UNIors & -.0146 & $(-.35)$ & .0773 & $(.17)$ & .5189 & $(3.49)$ \\
\hline HCTH & -.0210 & $(-.43)$ & .2883 & $(.81)$ & .1391 & $(.78)$ \\
\hline MAR & .0022 & $(.03)$ & .2708 & $(.46)$ & -.5184 & $(-2.14)$ \\
\hline WLFP & .0116 & $(.28)$ & .5285 & $(1.36)$ & .0370 & $(.23)$ \\
\hline$w W$ & .0046 & $(.93)$ & -.1899 & $(-1.01)$ & -.0005 & $(-.29)$ \\
\hline WKsON & -.0064 & $(-1.29)$ & .0027 & $(.14)$ & -.0037 & $(-.87)$ \\
\hline SIZE & .0025 & $(1.48)$ & .0032 & $(.23)$ & -.0177 & $(-2.61)$ \\
\hline UN & -.0011 & $(-.10)$ & .0224 & $(.21)$ & .0234 & $(.57)$ \\
\hline$R^{2}$ & .004 & & .060 & & .130 & \\
\hline $\mathbf{N}$ & 4213 & & 252 & & 280 & \\
\hline
\end{tabular}


affects the wage growth of men who separated from the fob much more strongly than that of stayers. In the older men sample, however, education has a significant effect only for those who quit. Therefore the results seem to suggest that education helpe to increase the gains from mobllity for young men and the gains from quitting at older ages.

The coefficients of experience are quite interesting in the young men's sample. In particular, as predicted in Part II, experience has a negative effect on the wage growth of stayers. Note, however, that experience 1s positive (though very waak) for both quitters and layoffs, Indicating that the accumulation of labor market experience may be helpful in creating the gains from mobility. A similar pattern is found for older men: experience has a negative effect on the wage growth of stayers, a positive effect on the wage growth of quitters and a zero effect on the wage growth of people who were laid off.

Other variables of sone interest include a union coefficient which seems to have a zero or negative effect on the wage growth of stayers. Marital status and the labor force particlpation atatus of the wife have significantly positive and negative effects respectively on the wage growth of the young men stayers. These effects can be interpreted by arguing that marriage increases the labor market investment incentives of males (perhaps due to the housohold division of labor), while if the wife works these incentives are diminished.

Finally, one of the most significant variables in the regression 1s the size of the local labor market. Thls variable has a strong positive effect on the wage growth of stayers. Surprisingly, it has a 
negative effect on the wage growth of older men who were laid off from their jobs.

\section{v. Summary}

In this paper we have presented a systematic empirical analyais of wage growth in the National Longltudinal Surveys of Young and Mature Men. We have demonstrated that labor turnover is a significant factor in understanding wage growth since it affecte both wage growth across jobs and wage growth within the fob. Some speciflc findings are summarized below.

1. Although the gains to quitting appear to be positive for young wen and zero or negative for older men, this was clarified by distinguishing anong three types of quits: quits due to finding a better fob, quits due to being dissatisfied with the current fob and quits due to personal reasons. It was then shown that in both age groups, individuals who quit because they sald they found a better fob experienced significant wage gains. At older ages a quit is mainly due to dissatisfaction with the current job and these types of quite do not in general significantly increase earnings. Since the nature of a quit changes over the life cycle, this is the reason for the age differences in the impacts of quits on wages.

2. We extended our analysis of the wage gains from mobility by comparing not only movers and stayers but individuals to themselves in the sense that we analyzed the individual's wage profile before, during and after the move to determine whether it had been significantly affected by mobility. It was shown that at least for the young men, this type of exercise led to the conclusion that a mover significantly gained from his actions. 
3. Labor turnover and wage growth within the fob are related through the observed positive correlation between wage growth and completed job tenure. Individuals who expected to remain on the job an additional year experienced steeper wage growth in the current period, ceteris paribus.

4. Since labor turnover was therefore found to have offsetting effects on wage growth, 1.e. leading to wage gains across fobs but flatter growth in shorter jobs, its effect on lifetime wage growth could not be predicted. Our empirical analysis showed, however, that, even after holding total labor force experience constant, there exists a strong positive correlation between length of current tenure and total iffe-cycle wage growth. Thus, while early mobility may pay, individuals who are still changing fobs later in life experience lower overall wage growth.

In summary, this paper has tried to show that labor turnover affects not only the growth of wages across fobs but also the rate at which wages grow on the job. It is therefore an important factor that must be taken account of in any study of the earnings distribution. 
APPENDIX A

Varlable List

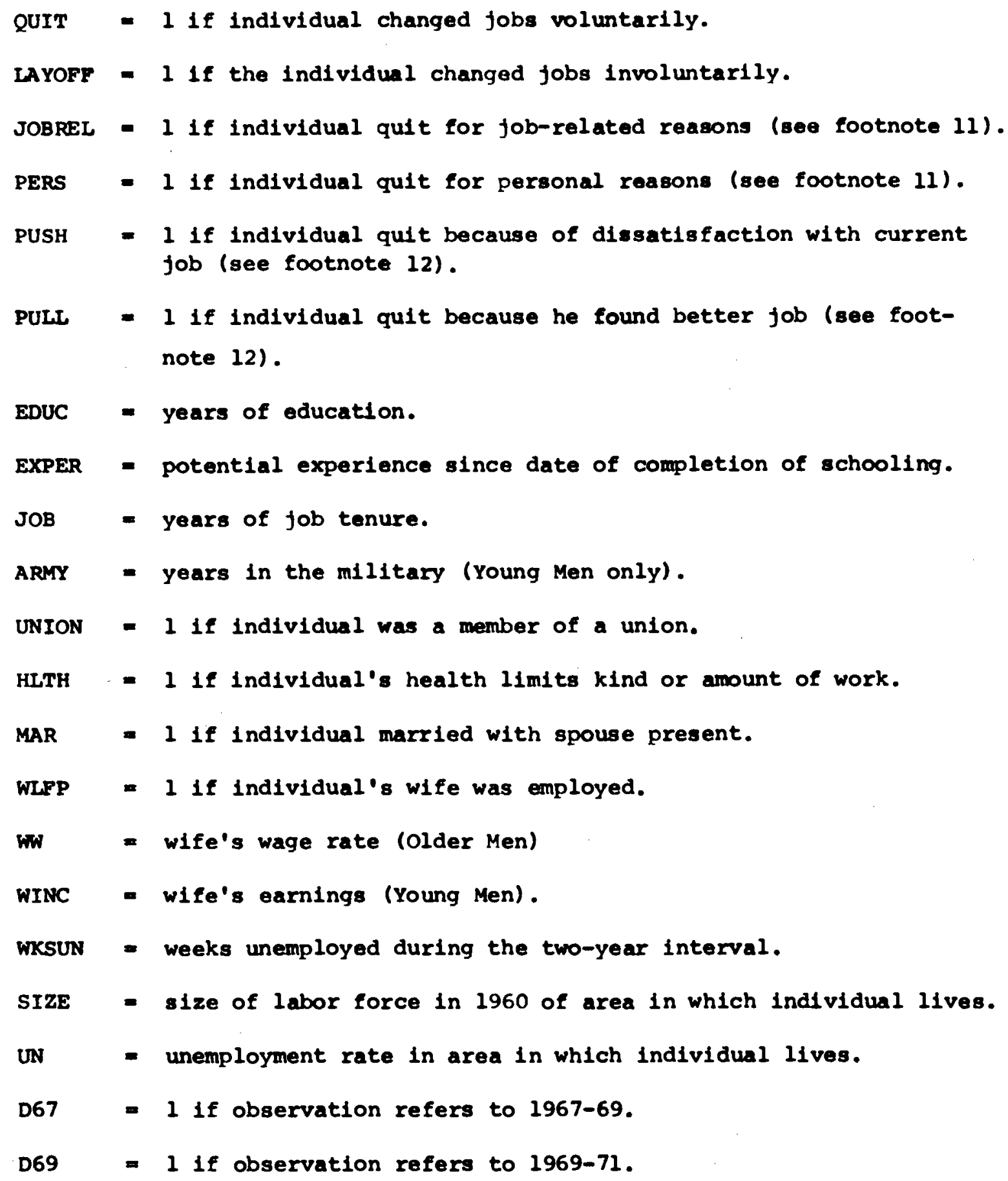




\section{BIBLIOGRAPHY}

Bartel, A.P., "The Economics of Migration: An Empirical Analyais with Special Reference to the Role of Job Mobllity," NBER Working Paper No. 198, August 1977.

Bartel, A.P. and G.J. Borfas, "Middle-Age Job Mobility: Its Determinants and Consequences," In S. Wolfbein (ed.) Men in the PreRetirement Years, Philadelphia, Temple University, 1977.

Becker, G.S., Human Capital, Second Edition, New York, NBER, 1975.

Ben-Porath, Y., "The Production of Human Capital and the Life Cycle of Earnings," Journal of Political Economy, August 1967.

Borjas, G.J., "Job Investment, Labor Mobility, and Earnings," unpublished Ph.D. Dissertation, Columbla University, 1975.

" "Job Mobility and Earnings over the Life Cycle," NBER Working Paper No. 233, February 1978.

Heckman, James J., "Life-Cycle Model of Earnings, Learning and Consumption," Journal of Political Economy, August 1976.

- "Heterogeneity and State Dependence in Dynamic Models of Labor Supply," this volume.

, "Sample Selection Bias as a Specification Error," forthcoming, Econometrica, 1978.

Jovanovic, B., "The Theory of Labor Turnover," mimeo.. 1978.

Jovanovic, B. and Mincer, J., "Labor Mobility and Wages," this volume.

Lazear, E., "Age, Experience and Wage Growth," American Economic Review, September 1976.

Mincer, J., "The Distribution of Labor Earnings," Journal of Economic Literature, October 1970.

Reiss, A.J., et. al., Occupations and Social Status, New York, Free Press, 1961.

Rosen, S., "Learning and Experience in the Labor Market," Journal of Human Resources, Summer 1972.

Sahota, G., "Theories of Personal Income Distribution: A Survey," Journal of Economic Literature, March 1978.

Wise, D., "Academic Achlevement and Job Performance," American Economic Review, June 1975. 
FOOTNOTES

"Columbla University Graduate School of Business and National Bureau of Economic Research.

* Univeraity of Calffornia, Santa Barbara and National Bureau of Econontc Rasearch.

${ }^{1}$ see Mfincer (1970) and Sahota (1978) for surveye of alternative explanations of the determinants of the earnings distribution.

${ }^{2}$ some exceptions are found in the papers by Lazear (1976) and W1se (1975).

In previous work (Bartel and Borjas, 1977) we have analyzed the problea of why people move. Here we concentrate on establishing the consequences of labor turnover for the Individual's wage-experience profile.

${ }^{4}$ Jovanovic (1978) provides a model that predicts wage growth on the fob based on the matching process between the individual and the E1rm.

${ }^{5}$ An extensive discussion of the role and effects of heterogeneity In the labor market is given in the Heckman article in this volume. Purther analysis of the problem, with labor turnover used as the focus, is provided by Jovanovic and Mincer in this volume.

${ }^{6}$ see Bartel (1977) for a detailed analysis of the relationship between job turnover and migration. 
7 These sample selection rules are far more serious than they appear to be. In particular, in the extreme age groups sampled in the NLS, a significant portion of turnover may be due to either retirement or school enrollment changes.

${ }^{8}$ There are two important qualifications to be noted here. Pirst, in the young men's NLS, many individuals were enrolled in school in the early years of the survey. Since we concentrate on the labor market behavior of men permanently attached to the labor force, we do not have observations for these individuals in the early years so that pooling cross-section and time series less than triples the number of observations. Secondly, the efficlency of ordinary least squares can be improved upon by utilizing one of the many methods now avallable for pooling cross-section and time-series. We do not pursue this refinement in this paper.

${ }^{9}$ An exact description of these variables is given in Appendix A. ${ }^{10}$ Recall that these numbers refer to the gains made over the twoyear period. To obtain annual effects of labor mobility, simply divide the coefficients by two.

${ }^{11}$ A fob-related quit is one that occurred because (a) the individual was dissatisfied with wages, hours, working conditions, and/or location of his job, (b) he disliked his fellow employees, or (c) he found a better job. A personal quit is one that occurred because of (a) health problems or (b) family reasons. For young men, 85 percent of the quits were fob-related while for the older men 73 percent were job related. 
12 pUSH is defined as a quit that occurred because (a) the individual was dissatisfled with wages, hours, working conditions or location of his fob; or (b) he disliked his fellow employees. PULl is a quit where the individual reports he found a better fob. Among the young men 50 percent of fob-related quits were "pulls" while for the older men only 35 percent of these quits were "pulls."

${ }^{13}$ The calculation uses the formula:

$$
P V=2,000 \cdot(\Delta w) \int_{0}^{T-1969} e^{-r t} d t
$$

where $\Delta w$ is the absolute wage increase, 2,000 hours are worked each year, and $T$ is the year of retirement. For young men, $T-1969$ is 43 years while for older men it is 10 years. We assume $r$ equals 10 percent.

${ }^{14}$ This hypothesis will be explored in detail in Part II.

15 These implications follow easily from life-cycle optintzation models developed by Ben-Porath (1967), Becker (1975) and Heckman (1976).

${ }^{16}$ The implications of this investment function for the wage level equation are derived in Borfas $(1975,1978)$.

${ }^{17}$ If eirm and individual investments are positively correlated, then clearly the firm too has a smaller incentive to lay off the worker, further lowering the probability of separation.

18 Although the derivations in this section are in terms of absolute wage growth, simflar equations can be derived for percentage wage 
growth. In particular, the analysis would then be conducted in terms of time-equivalent investment ratios. These ratios, in turn, would then be expected to decline both over the life cycle and within the job. Moreover, if higher levels of investment can only take place by spending a larger portion of work time investing, one would expect a positive correlation between these investment ratios and completed job tenure. Thus the analysis may carry over to percentage wage growth.

${ }^{19}$ These sample restrictions, of course, raise the possibility of sample selection bias; see Heckman (1978) for a thorough discussion of this problem.

${ }^{20}$ There are two possible reasons for the insignificance of REMTEN in the Young Men NLS. First, these men are in the very early years of their jobs when investment may not be taking place. Second, the usable sample is very small because during 1967-69 approximately half of the individuals were enrolled in school and are deleted from the sample; among the remainting 50 percent, the fob separation rate is very high thus resulting in further deletions. It is interesting to note that by enlarging the young men's sample to include individuals who did not leave the fob by 1973 and assigning an arbitrary value of 10 for REMTEN for these individuals, the REMTEN coofficient becomes positive and significant.

21 We use .0125 rather than .025 because the wage growth equations refer to two-year intervals. 
${ }^{22}$ Note that the coefficient of REMTEN is never significant in colum 3.2 when we deal with percentage wage growth. In principle, the correlation between investment and completed tenure need hold only in terms of dollar investment costs and not in terms of timeequivalent investment ratios since it is not clear a priori how Initial earnings capacities are correlated with completed fob tenure.

23 The problem of heterogeneity versus state dependence is discussed in detall in the Heckman and Jovanovic and Mincer papers included in this volume.

${ }^{24}$ of course, the results could also be consistent with the hypothesis that wages grow on the job because of a successful "match" between employer and employee. In other words, an individual's mobility ultimately led to his finding a firm in which he was able to "move up the ladder."

${ }^{25}$ The Duncan Index is described in Reiss (1961). It is very highly correlated with earninge in the occupation. 